\title{
Combined TLR2 and TLR4 ligation in the context of bacterial or helminth extracts in human monocyte derived dendritic cells: molecular correlates for Th I/Th2 polarization
}

\author{
Elly van Riet ${ }^{\dagger 1,5}$, Bart Everts ${ }^{\dagger 1}$, Kim Retra ${ }^{1,2}$, Marion Phylipsen ${ }^{1}$, Jaap J van \\ Hellemond ${ }^{2,3}$, Aloysius GM Tielens' ${ }^{2,3}$, Desiree van der Kleij ${ }^{1,4}$,
} Franca C Hartgers ${ }^{1}$ and Maria Yazdanbakhsh ${ }^{* 1}$

\begin{abstract}
Address: ${ }^{1}$ Department of Parasitology, Leiden University Medical Center, Leiden, The Netherlands, ${ }^{2}$ Department of Biochemistry and Cell Biology, Faculty of Veterinary Medicine, Utrecht University, Utrecht, The Netherlands, ${ }^{3}$ Department of Medical Microbiology and Infectious Diseases, Erasmus MC University Medical Center, Rotterdam, The Netherlands, ${ }^{4}$ TNO Defense, Security and Safety, Business Unit Biological and Chemical Protection, Rijswijk, The Netherlands and ${ }^{5}$ Division of Drug Delivery Technology, Leiden Amsterdam Center for Drug Research (LACDR), Leiden, The Netherlands

Email: Elly van Riet - evanriet@lacdr.leidenuniv.nl; Bart Everts - b.everts@lumc.nl; Kim Retra - retra@few.vu.nl;

Marion Phylipsen - m.phylipsen@lumc.nl; Jaap J van Hellemond - j.vanhellemond@erasmusmc.nl; Aloysius GM Tielens - a.g.m.tielens@uu.nl; Desiree van der Kleij - desiree.vanderkleij@tno.nl; Franca C Hartgers - f.c.hartgers@lumc.nl; Maria Yazdanbakhsh* - m.yazdanbakhsh@lumc.nl * Corresponding author †Equal contributors
\end{abstract}

Published: 4 February 2009

BMC Immunology 2009, 10:9 doi:10.1186/1471-2172-10-9

This article is available from: http://www.biomedcentral.com/I47I-2/72/10/9

(c) 2009 van Riet et al; licensee BioMed Central Ltd.

This is an Open Access article distributed under the terms of the Creative Commons Attribution License (http://creativecommons.org/licenses/by/2.0), which permits unrestricted use, distribution, and reproduction in any medium, provided the original work is properly cited.

\begin{abstract}
Background: Recognition of pathogens by dendritic cells (DCs) through interaction with pattern recognition receptors, including Toll like receptors (TLR), is crucial for the initiation of appropriate polarized $\mathrm{T}$ helper $(\mathrm{Th})$ cell responses. Yet, the characteristics and differences in molecular profiles of DCs with different T cell polarizing capacities are still poorly defined. To address this issue, the molecular profile of human monocyte derived DCs was characterized after exposure to TLR4 ligand LPS in combination with the ThI promoting bacterial extracts from Listeria monocytogenes and Escherichia coli or the Th2 promoting helminth derived phospholipids from Schistosoma mansoni and Ascaris lumbricoides, all with TLR2 activating capacity.
\end{abstract}

Results: With regard to the signalling pathways activated upon exposure to LPS and the TLR2 activating compounds, we find that the ratio of activated Mitogen Activated Protein Kinases (MAPK) p-ERK/p-p38 is lower in DCs stimulated with the bacterial products compared to DCs stimulated with the helminth products, which correlates with the ThI and Th2 polarizing capacity of these compounds. Furthermore, analysis of the mRNA expression levels of a set of 25 carefully selected genes potentially involved in modulation of $T$ cell polarization revealed that the mRNA expression of notch ligand delta- 4 and transcription factor c-fos are differentially regulated and show a strong correlation with ThI and Th2 polarization, respectively.

Conclusion: This study shows that combined TLR2 and TLR4 activation in the context of different antigen sources can induce very distinct molecular profiles in DCs and suggests that the Th1/Th2 polarizing capacity of compounds can be predicted with the molecular signature they induce in DCs. 


\section{Background}

Dendritic cells (DCs) are antigen presenting cells that play a pivotal role in the initiation of adaptive immune responses. These cells function as sentinels in the periphery where they are able to recognize and respond to stimuli from the environment they reside in, some of which could be products from invading micro-organisms or helminths. Upon such exposures DCs undergo phenotypic changes that allow them to effectively migrate to lymph nodes and prime appropriate $\mathrm{T}$ cell responses $[1,2]$.

The type of compounds encountered by DCs will determine to a large extent the nature of the T cell polarization promoted by these DCs. For this, DCs have to be able to distinguish these different classes of molecules. To this end, DCs express several classes of pattern recognition receptors (PRR), such as Toll-like receptors (TLR), C-type lectin receptors, Nod-like receptors and RIG-I like receptors that are able to recognize specific pathogen derived components, the so-called pathogen associated molecular patterns (PAMP). Upon engagement of these receptors, signalling cascades are initiated that involve activation of the MAPK and Nuclear factor- $\mathrm{\kappa B}$ (NF- $\mathrm{\kappa B})$, and induction of expression of genes involved in DC maturation and the ability to prime and skew T cell responses [3]. It is known that intracellular organisms are primarily capable of instructing DCs to induce Th1 responses [4], whereas extracts of parasitic helminths have been demonstrated to drive Th2 skewed responses [4-6].

Relatively much is known about the signalling pathways in DCs induced after triggering of PRR [3,7-9], however, the molecular characteristics that are different for DCs that have been activated by Th 1 or Th 2 promoting PAMP are much less understood $[10,11]$. We set out to address this issue by characterizing human monocyte derived DCs after exposure to maturation stimulus LPS, in combination with bacterial and helminth derived products. The characterization of the DCs comprised gene expression analysis of 25 genes that have been linked to activation and $\mathrm{T}$ cell polarizing properties of DCs. These molecular profiles of the DCs were correlated to their T cell polarizing capacity. In this study we used Gram-positive heat killed Listeria monocytogenes (HKLM) and Gram-negative Escherichia coli, both of which stimulate TLR2 and induce Th1 polarization. In addition, Schistosoma mansoni and Ascaris lumbricoides derived phosphatidylserine containing preparations (PS) were used, that also activate TLR2, but drive Th2 responses in the presence of TLR4 ligation by LPS [6]. We show that the signalling routes and the resulting mRNA expression profiles following stimulation by the bacterial and helminth derived products are very distinct. This indicates that not all extracts that contain TLR2 activating components modulate DC programming by
LPS in a similar fashion and in addition suggests that there is a general molecular DC1 and DC2 signature that can be used to predict Th1 and Th2 skewing potential of DCs.

\section{Results \\ TLR2 activating components that induce ThI or Th2 polarization via DCs}

To study the molecular characteristics of DCs exposed to compounds that engage TLR2 and 4, yet lead to differential skewing of immune responses in terms of Th1 and Th2 induction, different pathogen derived products from bacterial or helminth origin with a known Th1 and Th2 inducing capacity were chosen and combined with LPS, as a reference maturation stimulus [6]. For this study Gramnegative E. coli and Gram-positive heat killed L. monocytogenes (HKLM) were used as bacterial stimuli that induce Th1 responses. A schistosome (a trematode) derived phosphatidylserine containing lipid preparation (schPS) and a similar preparation from the nematode worm $A$. lumbricoides (ascPS), both containing mainly phosphatidylserine species with two attached acyl chains and some lysophosphatidylserine species (with only a single attached acyl chain) (fig $1 \mathrm{~A}$ and $1 \mathrm{~B}$, respectively), were chosen as Th2 inducing compounds [6]. Stimulation of HEK cells transfected with TLR showed that all stimuli could activate TLR2, with additional weak and potent TLR4 stimulation by the helminth lipids and E. coli, respectively (fig. 1C). IFN- $\gamma$ and schistosome derived soluble egg antigen (SEA), stimuli that do not show TLR2 activating capacity in our experiments (fig. 1C), and induce Th1 and Th2 responses, respectively, were used as controls [6]. To assess the T cell polarizing capacity of DCs exposed to these compounds, stimulated human monocyte derived DCs were co-cultured for two weeks with allogeneic naïve $\mathrm{CD} 4{ }^{+} \mathrm{T}$ cells and IL-4 as well as IFN- $\gamma$ production was determined by intracellular staining upon $\mathrm{T}$ cell restimulation (fig. 1D). DCs were stimulated with the different compounds in the presence of LPS, to ensure equal maturation and to rule out potential effects on polarization due to differences in maturation status of the DCs. We found that in all conditions expression of maturation markers was significantly higher than levels measured on immature DCs and more similar to the levels induced by LPS alone (data not shown). As expected, E. coli induced a strong Th1 response comparable to DCs stimulated with IFN- $\gamma$, while HKLM induced a moderately polarized Th1 response. Conversely, the helminth derived compounds, as shown before for schPS [6], and SEA [4,6], but also the $A$. lumbricoides derived phospholipids instructed DCs to drive Th2 skewed responses with the strongest polarization induced by SEA (fig. 1D). Based on intracellular IL-17 staining there was no sign of Th17 induction by the differently conditioned DCs, which is in agreement with other studies $[12,13]$. 

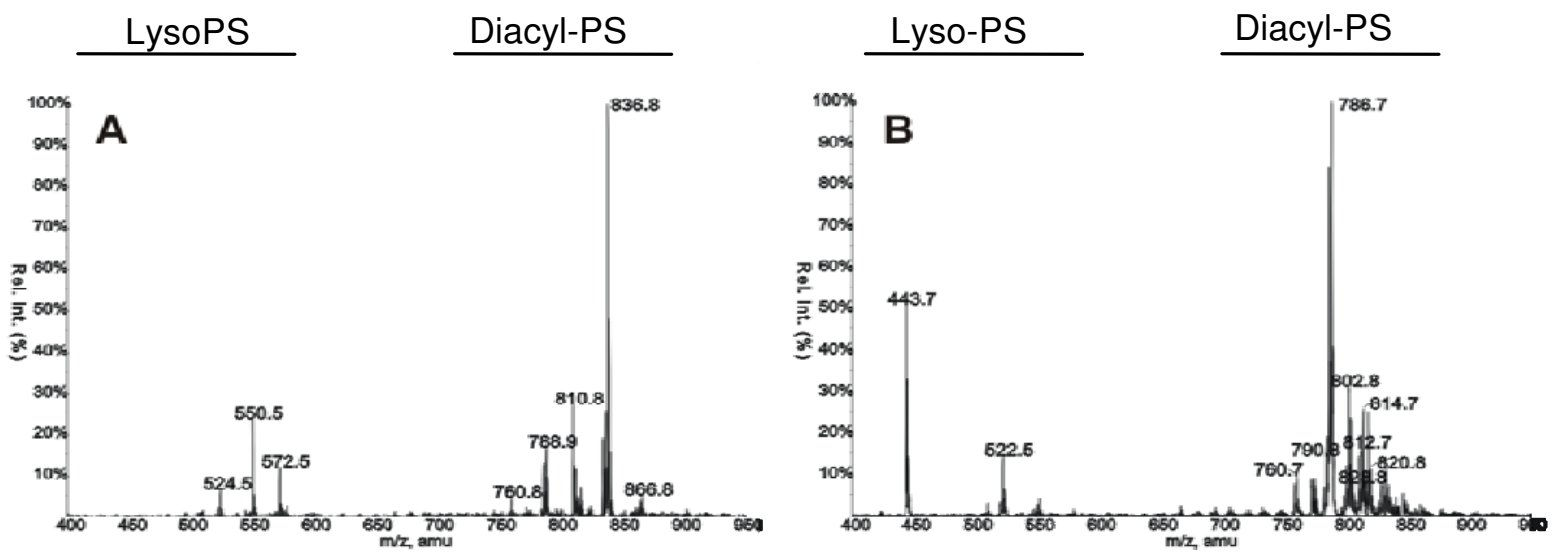

C



D

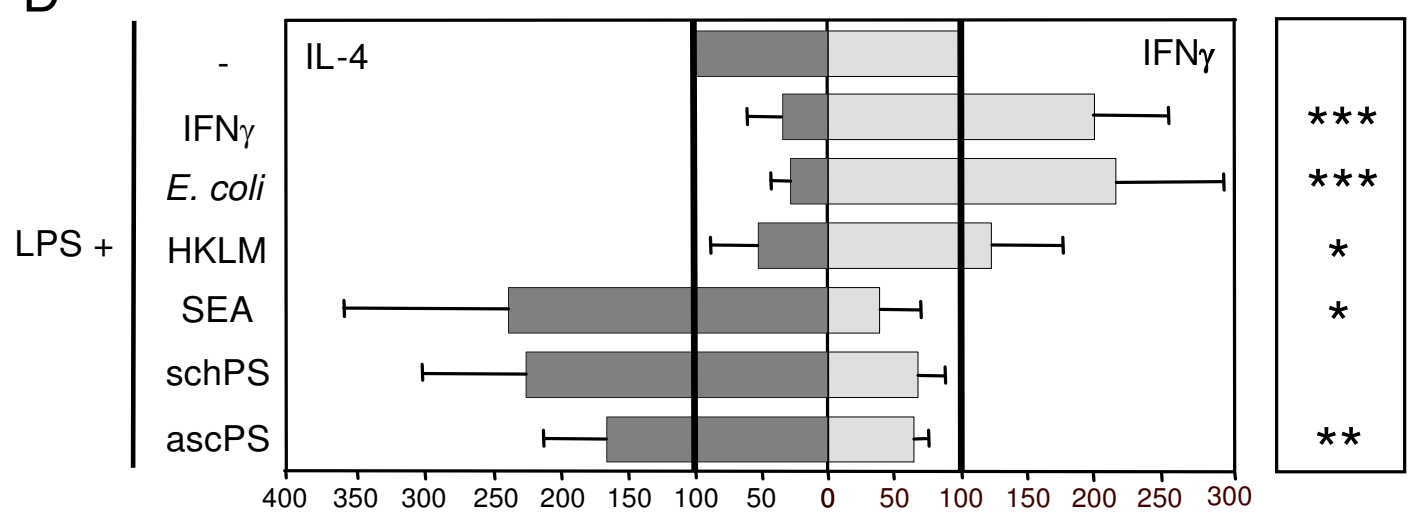

Percentage of cytokine producing $T$ cells

Figure I (see legend on next page) 
Figure I (see previous page)

TLR activation and T-cell polarization by the different compounds. Mass spectrometry analysis of schPS (A) and ascPS (B). Samples were analysed by LC/MSMS in the negative mode. Neutral loss scans of 87 amu, corresponding to the loss of serine from the phospholipid were obtained. The relative intensity is shown of the detected phosphatidylserine species (indicated by their distinct $\mathrm{m} / \mathrm{z}$ ratios). C. Activation of TLR2 and TLR4 transfected HEK 293 cells. HEK cells were stimulated and IL-8 production in response to activation is shown. CDI4 transfected HEK cells were used as negative controls (not shown). One representative experiment out of at least two independent experiments is shown, based on triplicate wells. \# $>40.000$ pg/ $\mathrm{ml}$. I a.u. is referring to lipids derived from 2 worm pairs $/ \mathrm{ml}$ or $12 \mathrm{mg}$ of worm $/ \mathrm{ml}$ for SchPS and AscPS, respectively. D. T cell polarization was determined by measuring the percentages of cells with intracellular IFN- $\gamma$ and IL- 4 production by FACS analysis. T-cell polarization after LPS stimulation alone $(4,6 \pm 3,5 \%$ IL-4 and 33,9 \pm I 5, I\% IFN- $\gamma$ producing T cells, respectively) was set to $100 \%$ (indicated by the bold lines). Relative amounts of IFN- $\gamma$ and IL-4 positive T cells induced by the stimuli in the presence of LPS are given. Dark gray (left); IL-4, Light grey (right); IFN- $\gamma$. Error bars represent SD of the mean of at least 4 independent experiments where cytokines produced in T cells of single wells of cocultures were measured. Significant differences in IL-4/IFN- $\gamma$ ratio for the different conditions relative to the LPS control are depicted on the right side of the graph. $* P<0.05$, ** $\mathrm{p}<0.01$, *** $\mathrm{p}<0.001$.

\section{MAPK activation}

To obtain a better understanding of the molecular processes in DCs that could underlie the observed differences in T cell polarizing capacity of these helminth- and bacteria-derived compounds, we set out to investigate in more detail the molecular characteristics of DCs exposed to the different stimuli. To study the intracellular signalling routes activated upon exposure to the helminth and bacterial derived products, we analysed the activation of the MAPK. ERK (ERK1/2) and p38 are two effector kinases of the MAPK family and are known to play an important role in shaping of immune responses [14]. p38 has been shown to regulate DC maturation and pro-inflammatory responses, while activation of ERK has been related to anti-inflammatory and Th2 responses [15]. As has been described before [16], exposure of DCs to LPS alone led to preferential phosphorylation of p38 (fig. 2A, B). The Th1 promoting stimuli IFN- $\gamma$ and $E$. coli even further increased the activation of this MAPK resulting in a reduced $p$-ERK/ p-p38 ratio, 20 minutes after stimulation (fig $2 \mathrm{~B}, \mathrm{C}$ ), whereas for HKLM this ratio did not change. In contrast, the Th2 inducing compounds PS and SEA increased this ratio. Interestingly, the high $p$-ERK/p-p38 ratio induced by these Th2 polarizing stimuli was the result of different activation profiles for SEA versus the lipid preparations: SEA significantly induced phosphorylation of ERK, whereas the helminth derived lipids impaired p38 activation, but showed no effect on ERK activation (fig 2D and $2 \mathrm{E})$. The $p$-ERK/p-p38 ratio showed a positive correlation with Th2, and negative correlation with Th1 polarization $\left(R^{2}=0.36\right.$ and -0.47 , respectively, figure $2 F$ and $\left.2 G\right)$. In conclusion, for all components tested, the $p$-ERK/p-p38 ratio only 20 minutes after DC stimulation can be used to predict the outcome of the $\mathrm{T}$ cell response with regard to Th1 and Th2 polarization. This shows that very early events in DC activation already determine the fate of the DCs in terms of their T cell polarizing capacity.

\section{Gene expression analysis}

To further characterize the molecular profile of the differentially stimulated DCs we performed mRNA expression analysis, using real-time PCR, on a selected set of genes involved in TLR signalling and T cell polarization (table $1[4,15,17-48]$, Figure 3A). Upon maturation with LPS, the expression of most genes was increased (data not shown). All data shown are relative to what is seen in mature DCs without any polarizing agents added, i.e. DCs stimulated with LPS. Stimulation of DCs from different individuals with the same stimulus showed very consistent profiles (data not shown). Clustering analysis revealed that the gene expression profiles of Th1 and Th2 polarizing agents clustered in separate groups (top of figure $3 \mathrm{~A}$ ). Within the Th1 stimuli, DCs exposed to bacterial products derived of L. monocytogenes and E. coli had a remarkably similar profile that was different from the profile induced by IFN- $\gamma$. For the Th2 stimuli, both helminth derived lipid preparations showed a very comparable profile, which resembled the expression profile induced by SEA for most of the genes (fig 3A). However, expression levels in PS pulsed DCs were generally lower than in SEA stimulated DCs which is in accordance with the less pronounced effects on activation of the MAPK by the PS preparations.

Next, we related expression levels of individual genes to the $\mathrm{T}$ cell polarizing capacities of the DCs, to identify potential mechanisms through which different pathogen derived compounds induce differential $\mathrm{T}$ cell polarization. Members of the IL-12 cytokine family are well known for driving Th1 polarization [1]. Indeed the expression of both IL-12 p40 and p35, but also IL-23 p19 were shown to be upregulated in DCs stimulated with Th1 inducing stimuli and reduced in DCs stimulated with helminth derived compounds (fig. 3A). This was confirmed at the protein level when IL-12 and IL-23 production by DCs were measured by ELISA (Fig 3B, C). 

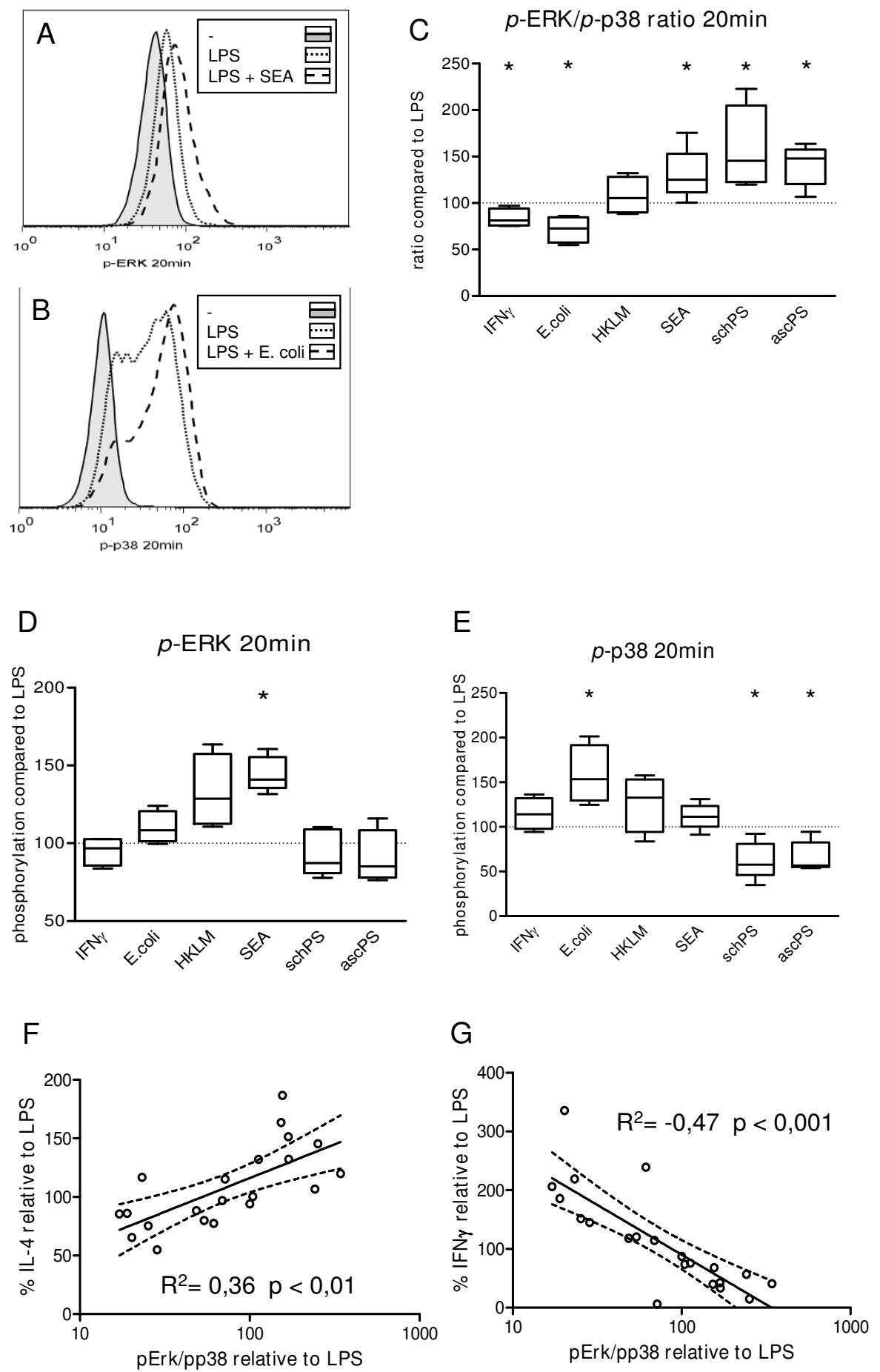

Figure 2

MAPK activation in DCs. Representative histograms of (A) ERK and (B) p38 phosphorylation in DCs 20 minutes after stimulation. C-E. Ratios of p-ERK/p-p38 (C), phosphorylation of ERK (D) and p38 (E) 20 minutes after stimulation in the presence of LPS. Expression induced by LPS (MFI of $49 \pm 12$ for $p$-ERK and $16 \pm 9$ for $p$-p38) was set to $100 \%$ (dashed line). Relative expression levels or ratios are shown. $* P<0.05$ compared to LPS stimulation. $F$ and $G$. Correlation of $p$-ERK/p-p38 ratio and IL-4 (F) or IFN- $\gamma(\mathrm{G})$ production by T-cells. All data are relative to stimulation with LPS only and combined results from 4 independent experiments are shown. 
A




$\mathrm{B}$

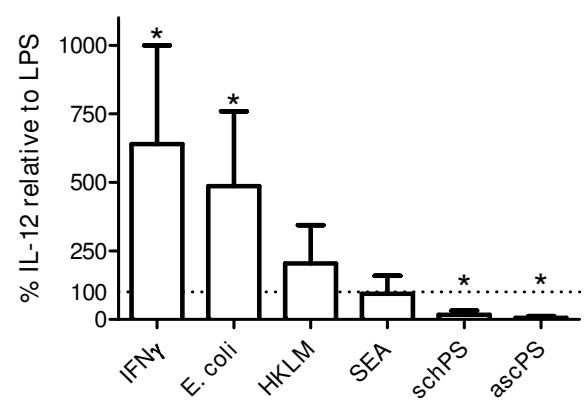

1. Cytokines \& chemokines

2. Toll like receptor signalling

3. Modulators of T cell activation \& polarization

a. Intracellular

b. Membrane bound
C

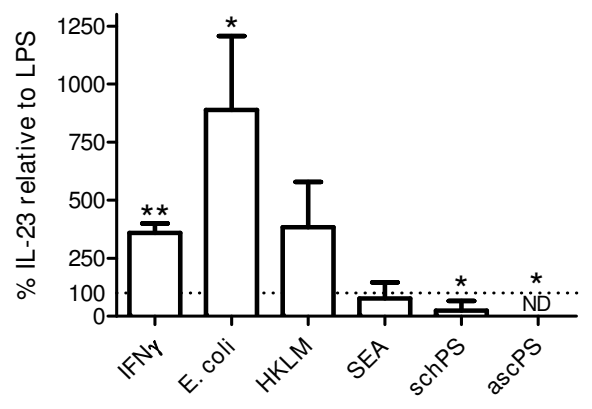



Figure 3

Distinct mRNA expression levels after stimulation of immature DCs with ThI and Th2 inducing compounds. A. mRNA expression levels of the different genes compared to LPS (representing a value of I). Green and red colours represent expression levels higher and lower, respectively, relative to LPS pulsed DCs. Expression was determined by real-time PCR with TAF-I as housekeeping gene. Stimuli were clustered hierarchically according to expression profiles (top of figure). B and C. Amount of IL- 12 p70 and IL-23 present in the supernatant of DCs 48 hours after stimulation, relative to the amount produced in the presence of LPS only $(2518 \pm 1733 \mathrm{pg} / \mathrm{ml} \mathrm{IL-12} \mathrm{\&} 230 \pm 195 \mathrm{pg} / \mathrm{ml} \mathrm{IL}-23)$. ND: not detectable, $* \mathrm{p}<0.05$, ** $\mathrm{p}<$ 0.01 compared to LPS stimulation only. D and E. Association of delta-4 (D) and c-fos (E) mRNA expression levels with T cell polarization for TLR2 activating stimuli. Diamonds represent HKLM or E. coli, circles the helminth derived lipids. Relative expression levels to LPS control condition (set to I) from at least 3 independent experiments are shown. 
Table I: Description of genes

\begin{tabular}{|c|c|c|c|c|}
\hline & & Gene & Function & References \\
\hline \multirow[t]{8}{*}{ Cytokines \& chemokines } & & IL- 12 p35 & $\begin{array}{l}\text { Together with p } 40 \text { forms the cytokine IL- } 12 \text { involved } \\
\text { in Th I polarization }\end{array}$ & {$[4,22]$} \\
\hline & & IL- 12 p 40 & $\begin{array}{l}\text { Together with p } 35 \text { forms the cytokine IL- } 12 \text { involved } \\
\text { in Th I polarization }\end{array}$ & {$[4,22]$} \\
\hline & & IL-23 pl9 & $\begin{array}{l}\text { Together with } \mathrm{p} 40 \text { forms cytokine IL- } 23 \text { in DCs } \\
\text { which augments ThI and ThI } 7 \text { responses }\end{array}$ & {$[26,32,36]$} \\
\hline & & TNF- $\alpha$ & $\begin{array}{l}\text { General pro-inflammatory cytokine mediating local } \\
\text { inflammation. Its expression is dependent on NF-k } \beta \\
\text { signalling }\end{array}$ & {$[17]$} \\
\hline & & CXCL-10 (IP-I0) & $\begin{array}{l}\text { Chemotactic factor for T cells. Its expression is } \\
\text { dependent on the IFN-responsive gene pathway }\end{array}$ & {$[35,45]$} \\
\hline & & CCL22 & $\begin{array}{l}\text { Chemokine involved in recruitment of Th2 effector } \\
\text { cells }\end{array}$ & {$[27]$} \\
\hline & & TGF- $\beta$ & $\begin{array}{l}\text { Cytokine with anti-inflammatory properties, by } \\
\text { inhibiting activity and function of both T cells and DCs }\end{array}$ & {$[34,42]$} \\
\hline & & IL-10 & $\begin{array}{l}\text { Cytokine that potently suppresses immune responses } \\
\text { and in particular DCs and T cell responses, by } \\
\text { downregulating pro-inflammatory effectors }\end{array}$ & {$[34,37]$} \\
\hline \multirow[t]{7}{*}{ Toll like receptor signalling } & & TLR2 & $\begin{array}{l}\text { Receptor of innate immunity for recognition of mainly } \\
\text { lipid containing compounds }\end{array}$ & {$[19,43]$} \\
\hline & & $\begin{array}{l}\text { TLR4 } \\
\text { MyD88 }\end{array}$ & $\begin{array}{l}\text { Receptor of innate immunity for recognition of LPS } \\
\text { Proximal, most common adaptor of TLR signalling, } \\
\text { shared by all TLR except TLR3 }\end{array}$ & $\begin{array}{l}{[19,43]} \\
{[24,43]}\end{array}$ \\
\hline & & NOD2 & $\begin{array}{l}\text { Intracellular peptidoglycan receptor implicated in } \\
\text { activation of NF-kB but also in inhibition of TLR2 } \\
\text { signalling }\end{array}$ & {$[31,38,44]$} \\
\hline & & TRIF (TICAMI) & $\begin{array}{l}\text { TLR3 and TLR4 specific adaptor which mediates the } \\
\text { MyD88-independent pathway preferentially leading to } \\
\text { induction of IFN-responsive genes }\end{array}$ & {$[30,46]$} \\
\hline & & Tollip & Inhibitor of IRAK activity and thereby TLR signalling & [48] \\
\hline & & SOCS-I & $\begin{array}{l}\text { Inhibitor of LPS-TLR4 signalling pathway as well as } \\
\text { TLR induced JAK/STAT signalling. Potential negative } \\
\text { regulator of ThI responses }\end{array}$ & {$[20,47]$} \\
\hline & & SOCS-3 & $\begin{array}{l}\text { Inhibitor of JAK/STAT signalling but also positive } \\
\text { regulator of APC function by suppression of STAT3, } \\
\text { which normally inhibits TLR signalling. }\end{array}$ & {$[20,47]$} \\
\hline \multirow{9}{*}{$\begin{array}{l}\text { Modulators of } \mathrm{T} \text { cell } \\
\text { activation \& polarization }\end{array}$} & Intracellular & DUSP2 & Phosphatase modulating MAP kinase signalling balance & [33] \\
\hline & & IDO & $\begin{array}{l}\text { Enzyme that catabolizes tryptophan to kynurenines, } \\
\text { which are able to induce T cell apoptosis and } \\
\text { inhibition of proliferation. Expression induced by IFN- }\end{array}$ & {$[28]$} \\
\hline & & c-Fos & $\begin{array}{l}\gamma \\
\text { Transcription factor activated by MAP kinases which } \\
\text { induces IL- } 10 \text { production and is involved in DC } \\
\text { mediated Th2/anti-inflammatory responses }\end{array}$ & {$[15,18]$} \\
\hline & Membrane bound & PD-LI (B7-HI) & $\begin{array}{l}\text { Costimulatory molecule and ligand for PD-I on T- } \\
\text { cells. It has inhibitory function in T cell proliferation } \\
\text { and cytokine production. Might be stimulatory for } \\
\text { Th2 response }\end{array}$ & {$[25,29,40]$} \\
\hline & & PD-L2 (B7-DC) & $\begin{array}{l}\text { Costimulatory molecule and ligand for PD-I on T- } \\
\text { cells. Reported to have synergic activity with other } \\
\text { costimulatory molecules as well as inhibitory activity } \\
\text { on T cell activation }\end{array}$ & {$[25,29,40]$} \\
\hline & & LIR-7 (ILT-I) & $\begin{array}{l}\text { Receptor with unknown ligand(s) with possible } \\
\text { immune suppressive properties, but also implicated in } \\
\text { immune activation }\end{array}$ & {$[23,4 I]$} \\
\hline & & Jagged-2 & $\begin{array}{l}\text { Ligand for notch-receptor on T cells; influences T cell } \\
\text { skewing }\end{array}$ & {$[2 I]$} \\
\hline & & Delta-4 & $\begin{array}{l}\text { Ligand for notch-receptor on T cells; influences T cell } \\
\text { skewing }\end{array}$ & {$[21,39]$} \\
\hline & & Delta-I & $\begin{array}{l}\text { Ligand for notch-receptor on T cells; influences T cell } \\
\text { skewing }\end{array}$ & {$[2 I]$} \\
\hline
\end{tabular}


With respect to $\mathrm{T}$ cell polarization, other genes of interest are the notch ligand family members delta-1, delta- 4 and jagged-2, since expression of delta and jagged on DCs has been associated with induction of Th1 and Th2 responses, respectively [21]. For jagged-2 and delta-1 no significant differences were found between the stimuli (figure 3A). However, delta- 4 was upregulated by the bacterial Th1 inducing stimuli, and downregulated by the Th 2 inducing lipids. Moreover, expression levels of delta- 4 correlated with the IL-4/IFN- $\gamma$ cytokine ratio produced by the T cells of the stimuli that activate TLR2 $\left(\mathrm{R}^{2}=-0.87\right.$, figure $\left.3 \mathrm{D}\right)$. Yet, in SEA and IFN- $\gamma$ stimulated DCs delta-4 expression was not altered. Therefore, Delta- 4 seems to associate with Thelper cell polarization only when TLR2 is also engaged.

Conversely, we found higher c-fos mRNA levels in PS and SEA pulsed DCs compared to HKLM and E. coli stimulated DCs. c-fos has been shown before to mediate SEA induced repression of IL-12 secretion by DCs [15]. Indeed, correlation analysis revealed that in DCs stimulated with bacterial products or helminth-derived lipids, mRNA levels of c-fos were positively correlated with Th2 induction $\left(\mathrm{R}^{2}=\right.$ 0.667 , fig 3E).

\section{Discussion}

DCs express a range of PRR that allow them to recognize different pathogens and initiate appropriate adaptive immune responses. Pivotal to this process is the proper integration of PRR derived signals into a molecular activation profile of DCs that leads to a particular T cell polarizing capacity. This study demonstrates that combined TLR2 and TLR4 activation in the context of different bacterial and helminth derived extracts can lead to very distinct molecular activation profiles of human DCs which correlate with their $\mathrm{T}$ cell polarizing capacity in terms of Th1 and Th2 skewing.

One of the major signalling cascades triggered upon engagement of TLR is the MAPK pathway. Differential activation of MAPK p38 and ERK in DCs has been associated with different level of maturation and cytokine production whereby p38 is thought to be important in mediating DC maturation and pro-inflammatory $\mathrm{T}$ cell responses, whereas ERK activation has more often been associated with anti-inflammatory and Th2 responses [49]. Earlier studies in human DCs have primarily focused on the role of different MAPK in DC activation, such as maturation and cytokine production [49]. We extended these studies, by analyzing for the first time the correlation between $p$-ERK/p-p38 ratios in human DCs and the degree of skewing of $\mathrm{T}$ cell responses by using various Th1 and Th2 inducing pathogen derived extracts. At 20 minutes after stimulation, we observed decreased $p$-ERK/pp38 ratios in the Th 1 promoting DCs. Of the two Th1 polarizing agents, E. coli induced more p38 activation, compared to HKLM, which is in agreement with the stronger Th1 polarization of the T cells (fig 1D). In contrast, all helminth-derived stimuli increased the $p$-ERK/pp38 ratio in the DCs. Comparison of the MAPK activation profile induced by the helminth-derived lipids with the one induced by SEA, revealed that SEA, like other helminth derived antigens such as LNFPIII [50] and ES-62 [51], induces a higher $p$-ERK/p-p38 ratio by increasing activation of ERK. On the other hand, the lipids influenced the $p$-ERK/p-p38 ratio by specifically impairing p38 phosphorylation. Thus, although the lipids share the capacity with other helminth antigens described so far to condition DCs for Th2 priming, they appear to achieve this differently exemplified by a different modulation of the MAP kinase signalling pathway. Taken together, the $p$ ERK/p-p38 ratio appears to be an important characteristic of antigen presenting cells exposed to pathogen derived compounds that skew responses towards Th2 or Th1.

Comparison of the mRNA expression profiles of TLR activating bacterial and helminth derived compounds revealed that, unlike the Th2 inducing phospholipids, exposure of DCs to Th1 promoting stimuli preferentially led to the induction of the pro-inflammatory cytokines IL12 and IL-23, both at the mRNA and the protein level. The degree of p38 activation, known to drive pro-inflammatory gene expression by these stimuli, was reflected by the level of expression of these cytokines. The higher expression levels of IL-12 and IL-23 in the E. coli and IFN- $\gamma$ stimulated DCs compared to HKLM pulsed DCs, probably contributes to the stronger Th1 induction seen with the former two stimuli.

While the immunological processes resulting in Th1 polarization have been extensively characterized, it is still poorly understood how exactly Th2 responses are initiated. One of the genes that was found to be positively associated with Th2 inducing DCs was the transcription factor c-fos. c-Fos has been shown to mediate IL-12 suppression in SEA pulsed DCs, which is generally thought to be a prerequisite for Th2 induction $[15,18]$. In addition, the observation that $\mathrm{c}$-fos mRNA expression levels were strongly correlated with Th2 induction not only for SEA, but also for PS, further supports the notion that this transcription factor plays a role in the promotion of helminth antigen dependent Th2 skewing. However, analysis of cfos at the protein level revealed that in PS pulsed DCs the increase of c-fos was lower and more transient, compared to SEA stimulated DCs (Everts et al unpublished data). Therefore, it remains to be established whether c-fos plays a similar role in PS pulsed DCs as has been shown for DCs modulated by SEA.

Notch ligands have been reported to play a role in Th1/ Th2 polarization by DCs [21]. While jagged-2 expression 
was initially implicated in DC mediated Th2 differentiation [21] more recent studies [52] show that jagged-2 has no role in Th2 induction by SEA activated DCs. Our findings are in accordance with these latter studies, since we did not observe any increased jagged-2 mRNA expression in our helminth derived stimulated DCs. Interestingly, another Notch ligand delta- 4 was found to be upregulated in DCs cocultured with bacterial compounds, while helminth derived compounds showed a decreased delta-4 expression. This in agreement with studies that show that delta-4 is involved in Th1 skewing [21], as well as inhibition of Th2 development [53].

Several studies have shown that TLR2 activation alone may lead to different outcomes; Th2 [18,54], Treg [55] as well as Th1 [56]. The variety of outcomes possible in the presence of TLR2 activation have been suggested to be the result of heterodimerization of TLR2 with different receptors, such as TLR1 or TLR6 $[57,58]$, or associations with other receptors including Nod-like receptors and C-type lectins $[11,59]$. In our study, the compounds used from helminths or bacteria are mixtures of antigens that would be expected to signal via additional receptors besides TLR2. E. coli has been shown to activate TLR4 and NOD1 $[60,61]$, whereas resistance to Listeria infection was related to the presence of functional NOD2 [62], indicating that this receptor is engaged by HKLM. Relatively little is known about Th2 skewing by the helminth derived compounds, but in a previous study of schistosomal lipids it was shown that TLR2 activation was not needed for Th2, but rather for regulatory responses [6]. Therefore, it is important to study the engagement of additional PRR along with TLR2 and TLR4 to fully understand the mechanisms that play a role in conditioning DCs for priming of Th2 responses $[62,63]$.

\section{Conclusion}

In conclusion, the study presented here indicates that TLR4 ligation on monocyte derived DCs in the context of TLR2 stimulating bacterial or helminth derived extracts leads to profoundly different outcomes in terms of activation or expression of various markers at the level of MAPK phosphorylation, mRNA expression and protein up- or downregulation. We show for the first time in human DCs that the levels of a selected number of molecular markers are strongly correlated with the T cell polarizing capacity of DCs. This not only gives us new insights about the processes involved in Th 1 and Th 2 polarization but it also suggests that there is a common molecular Th1 and Th2 signature in human DCs that can be used to predict the strength of induced Th skewing in terms of the Th1/Th2 balance.

\section{Methods \\ Antigen preparation}

Phosphatidylserine containing preparations (PS) were extracted from 4 gram of A. lumbricoides worms (expelled from infected humans) or from schistosomal worms, collected from golden hamsters 45-48 days after infection with $S$. mansoni, as described before [6]. Mass spectrometry was used to confirm the presence and composition of PS species in both lipid preparations, as described before [64]. Schistosomal egg antigen (SEA) was prepared from schistosomal eggs, collected from trypsin treated liver homogenate of the S. mansoni infected hamsters. E. coli (ATCC 11775) and L. monocytogenes (kind gift of J. van Dissel, LUMC, Leiden, The Netherlands) were grown at $37^{\circ} \mathrm{C}$ for $18 \mathrm{~h}$ in Brain Heart Infusion (BHI) bouillon (Biomerieux). Cultures were washed with PBS, quantified, and frozen in aliquots. In addition L. monocytogenes was heat inactivated for 2 hours and 45 minutes at $80^{\circ} \mathrm{C}$ before storage.

\section{TLR transfected HEK cell activation}

HEK-293-CD14, HEK-293-CD14/TLR2 and HEK-293CD14/TLR4 cells (a gift from Dr. E. Latz, University of Massachusetts) were maintained in DMEM culture medium, supplemented with $10 \%$ FCS, $10 \mu \mathrm{g} / \mathrm{ml}$ ciprofloxacin and $5 \mu \mathrm{g} / \mathrm{ml}$ puromycin. For stimulation experiments, cells were seeded at $3.5 \times 10^{4}$ cells/well in 96-well flatbottom plates and were stimulated the next day. For stimulation of HEK-293-CD14/TLR4 cells, $12.5 \%$ supernatant of MD- 2 transfected cells was added. IL- 8 production was measured in supernatants after 22 hours using a commercial kit (Sanquin, Amsterdam, The Netherlands), by following the manufacturer's recommendations.

\section{Dendritic cell culture and naïve $T$ cell polarization}

Monocytes were isolated and immature DCs were cultured as described before [6]. At day 6 or 7 immature DCs were matured with LPS (ultrapure, E. coli 0111 B4 strain, Invivogen $)(100 \mathrm{ng} / \mathrm{ml})$ in the presence of IFN- $\gamma(1000 \mathrm{U} /$ $\mathrm{ml}$ ), heat killed L. monocytogenes (HKLM; 108/ml), E. coli $\left(10^{7} / \mathrm{ml}\right)$, SEA $(50 \mu \mathrm{g} / \mathrm{ml})$, PS lipid extract derived from ascaris worms (an equivalent of $120 \mu \mathrm{g}$ of worm per $\mathrm{ml}$ ) or PS lipid extract derived from schistosomal worms (an equivalent of 20 worm-pairs per $\mathrm{ml}$ ). For RNA isolation, DCs were harvested 16 hours after stimulation, as pilot experiments in our lab indicated that the expression levels of most genes had changed at this time point. DCs were snap-frozen in liquid nitrogen and kept at $-80^{\circ} \mathrm{C}$ until RNA isolation. For measuring cytokine production by DCs and for co-culture with naïve T cells, DCs were matured for 48 hours after stimulation, after which secreted cytokines were measured in the harvested supernatant. Levels of IL12p70 were determined by ELISA using monoclonal antibodies 20C2 and biotinylated mouseanti-human IL-12 C8.6 (both Becton Dickinson) as coat- 
ing and detection antibodies, respectively. Levels of IL-23 were determined by ELISA using monoclonal antibodies ebio473p19 and biotinylated mouse-anti-human IL-12 C8.6 (both Becton Dickinson) as coating and detection antibodies, respectively. To determine $\mathrm{T}$ cell polarization, $5 \times 10^{3}$ mature DCs were cocultured with $2 \times 10^{4}$ naïve T cells that were purified using a human CD4+/CD45ROcolumn kit (R\&D, Minneapolis, $\mathrm{MN}$ ) in the presence of SEB $(100 \mathrm{pg} / \mathrm{ml}$; Sigma) in 96-well flat-bottom plates (Costar). On day 5, rhulL-2 (10 U/ml, Cetus Corp., Emeryville, CA) was added and the cultures were expanded for another 5-9 days. To measure the frequency of IL-4- and IFN- $\gamma$-producing T cells, Th cells were restimulated with PMA and ionomycin in the presence of brefeldinA (all Sigma) during 6 hours and stained with anti-hu-IL-4-PE and anti-hu-IFN- $\gamma$-FITC (both BD Biosciences).

\section{RNA isolation, DNase treatment and CDNA synthesis}

RNA isolation was performed using Trizol reagent (Invitrogen, Breda, The Netherlands) according to the manufacturers' instructions, with a minor modification: $3 \mu \mathrm{l}$ of glycogen (Invitrogen) was added to all samples after they were homogenized in Trizol for a few minutes at room temperature. DNAse treatment and cDNA synthesis were performed following standard procedures.

\section{Analysis of gene expression levels}

Primers and Taqman probes were provided as a Taqman gene expression kit (Applied Biosystems, Foster City, California) or designed using Primer Express (Applied Biosystems) and synthesized by Biolegio (Malden, The Netherlands) and Eurogentec (Seraing, Belgium), respectively (sequences available upon request). Real time qPCR was performed using Eurogentec PCR reagents, in a volume of $25 \mu \mathrm{l}$ on an ABI PRISM 7700 Sequence Detection System (SDS, Applied Biosystems), using the following program: 10 minutes at $95^{\circ} \mathrm{C}, 40$ cycles of 15 seconds denaturation at $95^{\circ} \mathrm{C}$ and 60 seconds annealing and amplification at $60^{\circ} \mathrm{C}$. Results were monitored and analysed with SDS software (Applied Biosystems).

Gene expression was normalized to the housekeeping gene TAF- 1 and calculations were performed as described using the $2^{-\Delta \Delta C}$ method [65]. Analysis of the expression of 6 different housekeeping genes in a subset of the samples indicated that TAF-1 was the most stable housekeeping gene in our samples upon stimulation. Spotfire software http://spotfire.tibco.com was used to generate a heatmap and perform hierarchical clustering of the genes.

\section{MAPK activation analysis}

20 and 60 minutes after stimulation of immature DCs (day 6), cells were fixed for 10 minutes with $4 \%$ ultrapure formaldehyde (Polysciences) directly in the plate. Cells were harvested and washed twice in PBS/0.5\% BSA. Sub- sequently, the DCs were permeabilized in $700 \mu$ ice-cold $90 \%$ methanol in PBS in and left on ice for 30 minutes. Following two wash steps in PBS/0.5\%BSA intracellular staining was performed for 2 hours at room temperature in the dark with anti-phospho-p44/42 MAPK AF-488 (T202/Y204) and anti-phospho-p38 MAPK AF-647 (T180/Y182), (Cell Signalling Technology). After one wash in PBS/0.5\%BSA MAPK activation was determined by flow cytometry using a Becton Dickinson FACSCalibur flowcytometer (BD Biosciences) and analysed using FlowJo analysis software (Tree Star).

\section{Statistical analysis}

Data were analysed using SPSS (v14.0) and GraphPad Prism4. Differences among stimuli were analysed by a Mann-Whitney test. Differences relative to LPS stimulation were determined using a one sample t-test. Correlations between expression of genes and/or T-cell responses were calculated by a two-tailed Spearman's-rho test. Differences were considered significant when P-values were below 0.05 .

\section{Authors' contributions}

ER and BE participated in the design of the study, drafted the manuscript, and together with MP performed and analysed the dendritic cell experiments. KR, JH and AT were involved in isolation and characterization of the helminth derived lipids. DK, FH and MY were involved in designing and coordination of the study, and interpretation of the data. All authors were involved in revising the manuscript and all authors read and approved the final manuscript.

\section{Acknowledgements}

We would like to thank Yvonne Fillié and Alwin van der Ham for help with the DC experiments, Marion Schmitz for help with the isolation of lipids from helminths and Hermelijn Smits for critically reading the manuscript. This work was supported by the Dutch Organization for Scientific Research (NWO), Grant No ZONMW 912-03-048 and the European commission, contract number EEG LSHB-CT-2006-018996 GABRIEL.

\section{References}

I. Kapsenberg ML: Dendritic-cell control of pathogen-driven Tcell polarization. Nat Rev Immunol 2003, 3:984-993.

2. Colonna M, Pulendran B, Iwasaki A: Dendritic cells at the hostpathogen interface. Nat Immunol 2006, 7: I 17-120.

3. Granucci F, Zanoni I, Ricciardi-Castagnoli P: Central role of dendritic cells in the regulation and deregulation of immune responses. Cell Mol Life Sci 2008.

4. de Jong EC, Vieira PL, Kalinski P, Schuitemaker JH, Tanaka Y, Wierenga EA, et al.: Microbial compounds selectively induce Th1 cell-promoting or Th2 cell-promoting dendritic cells in vitro with diverse th cell-polarizing signals. J Immunol 2002, 168:1704-1709.

5. Yazdanbakhsh M, van den BA, Maizels RM: Th2 responses without atopy: immunoregulation in chronic helminth infections and reduced allergic disease. Trends Immunol 200I, 22:372-377.

6. Kleij D van der, Latz E, Brouwers JF, Kruize YC, Schmitz M, KurtJones EA, et al:: A novel host-parasite lipid cross-talk. Schistosomal lyso-phosphatidylserine acivates Toll-like receptor 2 
and affects immune polarization. J Biol Chem 2002, 277:48|22-48I29.

7. Iwasaki A, Medzhitov R: Toll-like receptor control of the adaptive immune responses. Nat Immunol 2004, 5:987-995.

8. Reis e Sousa : Toll-like receptors and dendritic cells: for whom the bug tolls. Semin Immunol 2004, 16:27-34.

9. Akira S, Uematsu S, Takeuchi O: Pathogen Recognition and Innate Immunity. Cell 2006, I 24:783-80I.

10. MacDonald AS, Maizels RM: Alarming dendritic cells for Th2 induction. J Exp Med 2008, 205: 13-17.

II. Underhill DM: Collaboration between the innate immune receptors dectin-I, TLRs, and Nods. Immunol Rev 2007 21 9:75-87.

12. Khayrullina $\mathrm{T}$, Yen JH, Jing $\mathrm{H}$, Ganea D: In vitro differentiation of dendritic cells in the presence of prostaglandin E2 alters the IL-I 2/IL-23 balance and promotes differentiation of ThI7 cells. J Immunol 2008, 18I:72I-735.

13. Acosta-Rodriguez EV, Napolitani G, Lanzavecchia A, Sallusto F: Interleukins I beta and 6 but not transforming growth factor-beta are essential for the differentiation of interleukin 17-producing human T helper cells. Nat Immunol 2007, 8:942-949.

14. Banerjee A, Gerondakis S: Coordinating TLR-activated signaling pathways in cells of the immune system. Immunol Cell Biol 2007, 85:420-424.

15. Dillon S, Agrawal A, Van Dyke T, Landreth G, McCauley L, Koh A, et al.: expDC-RNAA Toll-like receptor 2 ligand stimulates Th2 responses in vivo, via induction of extracellular signal-regulated kinase mitogen-activated protein kinase and c-Fos in dendritic cells. J Immunol 2004, I 72:4733-4743.

16. Han J, Lee JD, Bibbs L, Ulevitch RJ: A MAP kinase targeted by endotoxin and hyperosmolarity in mammalian cells. Science 1994, 265:808-8| I.

17. Aggarwal BB: Signalling pathways of the TNF superfamily: a double-edged sword. Nat Rev Immunol 2003, 3:745-756.

18. Agrawal S, Agrawal A, Doughty B, Gerwitz A, Blenis J, Van Dyke T, et al.: Cutting edge: different Toll-like receptor agonists instruct dendritic cells to induce distinct $T h$ responses via differential modulation of extracellular signal-regulated kinase-mitogen-activated protein kinase and c-Fos. J Immunol 2003, I7I:4984-4989.

19. Akira S, Takeda $\mathrm{K}$, Kaisho $\mathrm{T}$ : Toll-like receptors: critical proteins linking innate and acquired immunity. Nat Immunol 200I, 2:675-680.

20. Alexander WS, Starr R, Metcalf D, Nicholson SE, Farley A, Elefanty AG, et al: Suppressors of cytokine signaling (SOCS): negative regulators of signal transduction. J Leukoc Biol 1999, 66:588-592.

21. Amsen D, Blander JM, Lee GR, Tanigaki K, Honjo T, Flavell RA Instruction of distinct CD4 T helper cell fates by different notch ligands on antigen-presenting cells. Cell 2004, I I 7:515-526.

22. Balkhy HH, Heinzel FP: Endotoxin fails to induce IFN-gamma in endotoxin-tolerant mice: deficiencies in both IL- 12 heterodimer production and IL- 12 responsiveness. I Immunol 1999, 162:3633-3638.

23. Bleharski JR, Li H, Meinken C, Graeber TG, Ochoa MT, Yamamura M, et al:: Use of genetic profiling in leprosy to discriminate clinical forms of the disease. Science 2003, 30I:1527-1530.

24. Burns K, Martinon F, Esslinger C, Pahl H, Schneider P, Bodmer JL, et al.: MyD88, an adapter protein involved in interleukin-I signaling. J Biol Chem 1998, 273:12203-I2209.

25. Butte MJ, Keir ME, Phamduy TB, Sharpe AH, Freeman G]: Programmed death-I ligand I interacts specifically with the B7I costimulatory molecule to inhibit $\mathrm{T}$ cell responses. Immunity 2007, 27: III-122.

26. Chen Z, Laurence A, O'Shea Jj: Signal transduction pathways and transcriptional regulation in the control of $\mathrm{Th} 17$ differentiation. Semin Immunol 2007.

27. Delgado M, Gonzalez-Rey E, Ganea D: VIP/PACAP preferentially attract Th2 effectors through differential regulation of chemokine production by dendritic cells. FASEB J 2004, I8:|453-|455.

28. Grohmann U, Fallarino F, Puccetti P: Tolerance, DCs and tryptophan: much ado about IDO. Trends Immunol 2003, 24:242-248.

29. Habicht A, Kewalaramani R, Vu MD, Demirci G, Blazar BR, Sayegh $\mathrm{MH}$, et al: Striking dichotomy of PD-LI and PD-L2 pathways in regulating alloreactive CD4(+) and CD8(+) T cells in vivo. Am J Transplant 2007, 7:2683-2692.

30. Hardy MP, McGGettrick AF, O'Neill LA: Transcriptional regulation of the human TRIF (TIR domain-containing adaptor protein inducing interferon beta) gene. Biochem J 2004, 380:83-93.

31. Inohara N, Nunez G: NODs: intracellular proteins involved in inflammation and apoptosis. Nat Rev Immunol 2003, 3:37I-382.

32. Ivanov II, Zhou L, Littman DR: Transcriptional regulation of ThI 7 cell differentiation. Semin Immunol 2007.

33. Jeffrey KL, Brummer T, Rolph MS, Liu SM, Callejas NA, Grumont RJ, et al: Positive regulation of immune cell function and inflammatory responses by phosphatase PAC-I. Nat Immunol 2006, 7:274-283.

34. Kabelitz D, Wesch D, Oberg HH: Regulation of regulatory $\mathbf{T}$ cells: role of dendritic cells and toll-like receptors. Crit Rev Immunol 2006, 26:29I-306.

35. Kawai T, Takeuchi O, Fujita T, Inoue J, Muhlradt PF, Sato S, et al: Lipopolysaccharide stimulates the MyD88-independent pathway and results in activation of IFN-regulatory factor 3 and the expression of a subset of lipopolysaccharide-inducible genes. J Immunol 200I, 167:5887-5894

36. Langrish CL, McKenzie BS, Wilson NJ, de Waal MR, Kastelein RA, Cua DJ: IL- 2 and IL-23: master regulators of innate and adaptive immunity. Immunol Rev 2004, 202:96- 105.

37. Mahnke K, Johnson TS, Ring S, Enk AH: Tolerogenic dendritic cells and regulatory $T$ cells: a two-way relationship. J Dermatol Sci 2007, 46:159-167.

38. Pauleau AL, Murray PJ: Role of nod2 in the response of macrophages to toll-like receptor agonists. Mol Cell Biol 2003, 23:753।-7539.

39. Schaller MA, Neupane R, Rudd BD, Kunkel SL, Kallal LE, Lincoln P, et al.: Notch ligand Delta-like 4 regulates disease pathogenesis during respiratory viral infections by modulating Th2 cytokines. J Exp Med 2007, 204:2925-2934.

40. Sharpe AH, Wherry EJ, Ahmed R, Freeman GJ: The function of programmed cell death $I$ and its ligands in regulating autoimmunity and infection. Nat Immunol 2007, 8:239-245.

4I. Sloane DE, Tedla N, Awoniyi M, Macglashan DW Jr, Borges L, Austen $\mathrm{KF}$, et al.: Leukocyte immunoglobulin-like receptors: novel innate receptors for human basophil activation and inhibition. Blood 2004, 1 04:2832-2839.

42. Strobl H, Knapp W: TGF-betal regulation of dendritic cells. Microbes Infect 1999, I:1283-1290.

43. Takeda K, Akira S: TLR signaling pathways. Semin Immunol 2004 16:3-9.

44. Watanabe T, Kitani A, Murray PJ, Strober W: NOD2 is a negative regulator of Toll-like receptor 2-mediated $\mathrm{T}$ helper type I responses. Nat Immunol 2004, 5:800-808.

45. Weighardt H, Jusek G, Mages J, Lang R, Hoebe K, Beutler B, et al.: Identification of a TLR4- and TRIF-dependent activation program of dendritic cells. Eur J Immunol 2004, 34:558-564.

46. Yamamoto M, Sato S, Hemmi H, Hoshino K, Kaisho T, Sanjo H, et al: Role of adaptor TRIF in the MyD88-independent toll-like receptor signaling pathway. Science 2003, 30 I:640-643.

47. Yoshimura A, Naka T, Kubo M: SOCS proteins, cytokine signalling and immune regulation. Nat Rev Immunol 2007, 7:454-465.

48. Zhang G, Ghosh S: Negative regulation of toll-like receptormediated signaling by Tollip. J Biol Chem 2002, 277:7059-7065.

49. Nakahara T, Moroi Y, Uchi H, Furue M: Differential role of MAPK signaling in human dendritic cell maturation and ThI/Th2 engagement. J Dermatol Sci 2006, 42: I-I I.

50. Thomas PG, Carter MR, Atochina O, Da'Dara AA, Piskorska D, McGuire $E$, et al: Maturation of dendritic cell 2 phenotype by a helminth glycan uses a Toll-like receptor 4-dependent mechanism. J Immunol 2003, I 71:5837-584I.

5I. Goodridge HS, Harnett W, Liew FY, Harnett MM. Differential regulation of interleukin- 12 p40 and p35 induction via Erk mitogen-activated protein kinase-dependent and -independent mechanisms and the implications for bioactive IL- 12 and IL-23 responses. Immunology 2003, 109:4I5-425.

52. Worsley AG, Leibundgut-Landmann S, Slack E, Phng LK, Gerhardt H Sousa CR, et al:: Dendritic cell expression of the Notch ligand jagged2 is not essential for Th2 response induction in vivo. Eur J Immunol 2008, 38: 1043-1049. 
53. Sun J, Krawczyk C], Pearce E): Suppression of th2 cell development by notch ligands deltal and delta4. J Immunol 2008, 180:1655-1661.

54. Yang D, Chen Q, Su SB, Zhang P, Kurosaka K, Caspi RR, et al.: Eosinophil-derived neurotoxin acts as an alarmin to activate the TLR2-MyD88 signal pathway in dendritic cells and enhances Th2 immune responses. J Exp Med 2008, 205:79-90.

55. Netea MG, Sutmuller R, Hermann C, Graaf CA Van der, Meer JW Van der, van Krieken JH, et al.: Toll-like receptor 2 suppresses immunity against Candida albicans through induction of IL- 10 and regulatory T cells. J Immunol 2004, I 72:37|2-37।8.

56. Sieling PA, Chung W, Duong BT, Godowski PJ, Modlin RL: Toll-Like Receptor 2 Ligands as Adjuvants for Human ThI Responses. J Immunol 2003, I 70: 194-200.

57. Takeuchi O, Kawai T, Muhlradt PF, Morr M, Radolf JD, Zychlinsky A et al:: Discrimination of bacterial lipoproteins by Toll-like receptor 6. Int Immunol 200I, 13:933-940.

58. Takeuchi O, Sato S, Horiuchi T, Hoshino K, Takeda K, Dong Z, et al.: Cutting edge: role of Toll-like receptor $I$ in mediating immune response to microbial lipoproteins. J Immunol 2002, 169:10-14.

59. Gringhuis SI, den Dunnen J, Litjens M, van het Hof B, van Kooyk Y, Geijtenbeek TBH: C-Type Lectin DC-SIGN Modulates Toll-like Receptor Signaling via Raf-I Kinase-Dependent Acetylation of Transcription Factor NF-[kappa]B. Immunity 2007, 26:605-616.

60. Takeuchi O, Hoshino K, Kawai T, Sanjo H, Takada H, Ogawa T, et al: Differential roles of TLR2 and TLR4 in recognition of gramnegative and gram-positive bacterial cell wall components. Immunity 1999, II:443-45I.

61. Kim JG, Lee SJ, Kagnoff MF: NodI is an essential signal transducer in intestinal epithelial cells infected with bacteria that avoid recognition by toll-like receptors. Infect Immun 2004, 72: |487-| 495

62. Kobayashi KS, Chamaillard M, Ogura $\mathrm{Y}$, Henegariu O, Inohara $\mathrm{N}$, Nunez G, et al: Nod2-dependent regulation of innate and adaptive immunity in the intestinal tract. Science 2005 307:73I-734.

63. Lee MS, Kim Y]: Signaling pathways downstream of patternrecognition receptors and their cross talk. Annu Rev Biochem 2007, 76:447-480.

64. Retra K, van Riet E, Adegnika AA, Everts B, van Geest $S$, Kremsner PG, et al.: Immunologic activity of schistosomal and bacteria TLR2 ligands in Gabonese children. Parasite Immunol 2008 , 30:39-46.

65. The Perkin-Elmer Corporation: User bulletin \#2. ABI Prism 7700 Sequence Detection system. P/N 4303859 Rev.A, Stock No 777802-00I. 2005.
Publish with Bio Med Central and every scientist can read your work free of charge

"BioMed Central will be the most significant development for disseminating the results of biomedical research in our lifetime. "

Sir Paul Nurse, Cancer Research UK

Your research papers will be:

- available free of charge to the entire biomedical community

- peer reviewed and published immediately upon acceptance

- cited in PubMed and archived on PubMed Central

- yours - you keep the copyright
BioMedcentral 